\title{
高校生の体育授業にお打を走・投能力向上の可能性 一動作改善に着目して一
}

\author{
Possibility of improvement in running and overhand throwing abilities of high school students \\ through regular physical education classes \\ - The importance of fundamental movements practice for appropriate motor pattern -

$\begin{array}{lll}\text { 宮 㠃 } & \text { 世明 } & \text { 世 Akiyo MIYAZAKI } \\ \text { 尾 縣 } & \text { 貢: Mitsugi OGATA }\end{array}$ \\ 筑波大学人間総合科学研究科：Graduate School of Comprehensive Human Sciences, University of \\ Tsukuba 1-1-1 Tennodai,Tsukuba,Ibaragi,305-8574,JAPAN
}

\begin{abstract}
The purpose of this study was to explain the possibility of improvement in running and overhand throwing abilities in high-school students through regular physical education classes. The subjects were 117boys and 95 girls in the second grade of a high school. The subjects performed $100 \mathrm{~m}$ run and ball throws before and after physical education classes, 10 times during 4weeks. The physical education classes were consisted of some kind of teaching materials for running and overhand throwing skills. The running and throwing motions were recorded with a VTR camera from the side view. By the posterior observation of the videotape, motor pattern of running and throwing was evaluated individually. The results were compared before and after the classes, to explain significant differences by the t-tests.

The results were summarized as follows;

1) The means of running time decreased significantly, and throwing distance increased significantly both in boys and girls.

2) Improvement in running time and throwing distance after trials was remarkable in lower revel subjects, before learning. And the some differences were found in the tendency by sex and the events.

3) There was a large difference of running time and throwing distance as well in its growth in terms of sex. But the result of evaluated running and throwing motions shows that girls were more improved than boys. These results explain that it is possible to improve running and throwing abilities in high school students, and it is suggested that running and throwing (fundamental movements) practice for acquirement of appropriate motor pattern is important through regular physical education classes.
\end{abstract}




\section{1. 研究の目的}

近年、遊びの質の変容や生活時間の変化などが 原因と考えられる、子どもの体力の低下が問題に なっている。この幼児期・児童期の体力の低下は、 成人に近い高校期の体力にも影響を与えている。 一般に男子は高校期に体力のピークを迎え、女子 は中学期をピークに、その後は下降を始死とい われている。そのため、この時期に体力を高めて おくことは人生において重要な意味を持つといえ る。

幼児期からの運動能力の発達は、体力と運動動 作の発達に支えられているということができる。 幼览から児童の時期には、運動の量的変化と質的 変化は関連性が高く、運動成就の調整力がより重 要な要因になると指摘している研究もある（金・ 松浦，1988）。体力に優れていても運動動作が未 習熟であれば、高いパフォーマンスが発揮できな いということは幼児期・览童期に限らない。体力 に見合った運動能力の発揮には運動動作の習得が 不可欠であり、体力が同じようなレベルにある場 合には、運動動作に優れている方が発揮されるパ フォーマンスは高いと考えられる。また、小、中、 高校の学習指導要領にも「運動技能の向上」が取 り上げられ、体育授業の中で基礎的な運動動作の 習得が課題とされている。

基礎的な運動の代表的なものとして走・跳・投 の運動があげられる。なかでも走運動は、運動棈 造が比較的単純な循環運動で、生得的要素が大き いとされている。その運動動作は発育にともなっ て自然に習得できるものとみなされるのが一般的 で、体育授業に扔いて走運動自体を指導されるこ とは稀である。走運動の技能学習が見過される理 由の一つとして走能力が基礎的体力として捉えら れ、記録のみに目が向けられやすい事があげられ る。運動機会の少ない現代の子ども達は、かつて は遊びや日常生活の中で自然に身についていた 「走る」という動作さえもぎこちないまま成長し、 体育授業において技能学習が軽視されることでさ らに低い走能力にとどまっていると考えられる。 走運動がさまざまな運動の基本となることから も、走運動技能の学習の必要性は明らかである。 思春期以降、疾走速度の性差は明確になるが、そ の要因として形態的、体力的な要因の他に走動作
の違いが挙げられる。女子は男子に比べていずれ の年齢においても上下動が大きい走り方であると されている（宮丸，1990）。疾走速度の増大のた めには疾走中の支持時間が短いこと、ピッチが高 い、身体重心の上下動が小さいことが必要とされ る。そのための具体的な動きとして、支持脚の足 先を後方へキックする動き、自由脚を前方へ加速 するような動き、足先を後方へ振り戻すような動 きが挙げられる（加藤ら，1992）。このような動 作は自然に獲得されるものではなく、指導を通し て習得されるものである。

それに対して投動作は人間に特有の動作とさ れ、自分の身体以外の物を操作したり、エネルギ 一を与えたりするという意味では、走・跳運動と は異質な運動であるといえる。投げにはいろいろ な方法があり、投げる物に適した方法の選択が必 要になる。そのなかでさまざまなスポーツにおい て使用頻度の高い片手の上手投げの研究が多くな されており、本研究でもこれを取り上げた。片手 の上手投げに関して高校生の現状をみると、特に 女子の大半の動作が未熟で、女子ほどではないに せよ男子にも未熟な動作が見られ、改善が望まれ る。その理由として、走運動に対して投運動は運 動構造が複雑で、パフォーマンスの発揮に動作の 習得が大きく影響することがあげられる。この動 作の習得は幼少時の運動経験に左右されることか ら、現在の子供たらの投運動の経験の不足がうか がえる。走運動と同様に体育授業において「動作 の習得」に目を向けた指導がなされていないこと が予測され、投運動の技能学習の必要性が感じら れる。また、投運動は性差が大きいのも特徵で、 加齢につれて性差は大きくなり、6〜 7歳頃に顕 著となる。金・松浦（1988）の報告によれば、投 運動に招ける量的変化と質的変化には相関があ り、成長にともない記録は増大する。幼児期・児 童期には男女で体格に差がなくともパフォーマン スに差があることから、その差はフォームにある としている。このような女子の投動作のぎこちな さは特別な練習機会を持たない限り大きな変容は なく、成人にいたってもかなりの割合で未熟な投 動作の形態が見られる（出村ら，1993）。また、 投動作は他の打型のスポーツと運動構造上共通守 る点も多いとされている。投動作の習得はテニス、 
卓球、ゴルフ、バドミントンといったスポーツに おける、対象物を加速する多くの動作を優れたも のにしていくことに通じている。このようなこと から生涯スポーツと関わっていくためにも習得さ れるべき運動動作であるといえる（櫻井，1991）。

これまであげたような基礎的運動の発達やトレ ーニング効果などについては、成長の著しい幼 児・児童を対象に研究されたものが多く、高校生 に関するものは少ない。一般に高校期は成長が一 段落した時期とされ、女子に扔いては体力的にも 下降し始める時期であるため、成人と近いものと して捉えられることがその理由の一つと考えられ る。高校期以後の体育教育を考えると、大学進学 率が向上したとはいえ大学での体育授業は選択で あることが多く、高校期が学校での体育授業の最 後の機会である場合も多い。体育の授業でしか体 を動かさない子供たちの実情も踏まえ、体育授業 の運動機会としての意義、および生涯スポーツに つながる技能向上の意義は重要なものである。し かしながら、現在の高校の体育授業は種目選択制 の影響も受け、生徒たちの自主的な活動が中心で、 基礎的運動技能の指導は少ないと思われる。成長 の一段落した高校生の体育授業における運動能力 向上の可能性を探ることは、体育授業の意義にも 大きく関わるものである。

そこで本研究では、走運動と投運動の技能学習 を中心とした体育授業を行うことにより、高校生 が体育授業を通して、それらの運動動作を獲得ま たは改善し、走・投能力を向上させる可能性を明 らかにすることを目的とする。

\section{2。方法}

\section{(1) 対象者}

東京都文京区の T大学附属高等学校 2 年次に在 籍する男子 117 名、女子 95 名を対象とした。対象

\section{表 1 対象者の身体的特性}

\begin{tabular}{cccc}
\hline & & $\begin{array}{c}\text { 男子 } \\
(\mathrm{N}=117)\end{array}$ & $\begin{array}{c}\text { 女子 } \\
(\mathrm{N}=95)\end{array}$ \\
\hline \hline 身長 & 平均 & 1.703 & 1.589 \\
$(\mathrm{~m})$ & 標準偏差 & 0.058 & 0.052 \\
\hline 体重 & 平均 & 59.21 & 52.30 \\
$(\mathrm{~kg})$ & 標準偏差 & 7.44 & 5.81 \\
\hline
\end{tabular}

者の身体的特性を表1に示した。実施に当たって は本研究の内容と目的を十分に説明し、理解の上 同意を得た。

\section{（2）学習プログラムと学習の流れ}

本研究では 1 単位時間の授業の前半を走連動、 後半を投運動の学習内容で構成した50 分の授業 を10回実施した。このことにより全期間継続し て走、投両方の運動に取り組めるように工夫した。 授業者は全ての授業について、陸上競技を専門と する教師が一人で担当した。表 2 に学習プログラ ムの内容、図1に単元の学習の流れを示した。

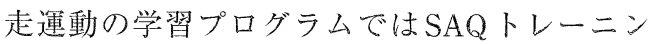
グのドリルを使った動き作りを継続して行った。 SAQトレーニングはS (Speed)、A (Agility)、Q (Quickness) の3つの概念から成り立ち、“速さ” の獲得を目的としている。陸上競技スプリントの SAQトレーニングの站らいは1）正しい歩行姿勢 を創る、2）身体の部分を意識する、3）神経の伝 達速度を高める、4）ランニングスキルの向上な どである（日本SAQ協会，1999）。本研究ではそ の代表的な教具であるミニハードルとラダーを使 用し、それぞれ 4 種類の動きを「正確に、速く」 行うことを目標として行った。また、その他にス プリント練習として、ストライド走、ミニハード ル走、フロートなどを行い、スタート練習も各種 行った。

投運動の学習プログラムでは小学校 $2 、 3$ 年生 を対象として考案された学習プログラム(尾縣ら， 2001）を使用して、投げの動き作りを行った。こ の学習プログラムは特別な運動学習経験のない女 子大学生を対象とした研究（尾縣ら，1996）にお いて、準備動作に重点をおいたトレーニングを行 ったところ、オーバーハンドスロー動作全㑂が習 熟し、遠投距離も有意に向上したことから、小学 生学対象に準備動作に重点を预いて考案されたも のである。授業で扱う教材としての条件を考慮し た基礎的運動プログラムであり、投運動の基礎を 指導するために適切であると判断した。ボールは 3 号ソフトボール (ケンコーGreen softball 12 イン チ）を使用した。授業全般を通して、よい動きの ポイントを示し、生徒相互にフォームチェックを 行わせ、良い運動イメージを持たせるよう指導し 
た。また、ボールだけでなくターボジャブを使用 し、いろいろなものを投げる経験とともに、陸上 競技の種目への発展も考慮した。また、補助資料 を作成し、他の種目の紹介や、競技の特徵や楽し み方など知識の面も考慮した。

\section{（3）測定}

学習の前後に $100 \mathrm{~m}$ 走抢よびソフトボール投げ の測定およびビデオ撮影を行った。100m 走では クラウチングスタートを用い、光電管を使用して 1 100 秒単位で測定した。試技は 1 回のみとし
た。

ソフトボール投げは「できるだけ遠くへ力いっ ぱい投げる」という指示により、新スポーツテス 卜実施要項（1999）を参考に、直径 $2 \mathrm{~m}$ の円の中 から約 30 度の有效角度線の中に遠投を実施し、 $1 \mathrm{~cm}$ 単位で測定した。試技には公認 3 号球を使用 し、記録の安定性を見るために5 回の測定を行っ た。

$100 \mathrm{~m}$ 走においてはスタートから $40 \mathrm{~m}$ 地点の側 方 $15 \mathrm{~m}$ に、ソフトボール投げにおいては被験者の 右 $15 \mathrm{~m}$ 地点にデジタルビデオカメラを設置し、動

\section{表 2 学習プログラムの内容}

$<$ 走運動 $>$

\begin{tabular}{|c|c|}
\hline 項目 & 内 \\
\hline ミニハードルドリル & スキッピング・ハイニー・片脚ジャンプ・両脚ジャンプ・スプリント等 \\
\hline ラダー & クイックラン・カリオカ・シャッフル・ッイスト等 \\
\hline ストライド走 & $\begin{array}{l}\text { グランドマーカーを一定間隔（1.7〜2.0m） に置き、間に接地して走りぬける } \\
\text { (助走 } 20 \mathrm{~m}+30 \mathrm{~m}) \text { 各自の歩幅にあったインターバルを選択 }\end{array}$ \\
\hline \multirow[t]{2}{*}{ ミニハードル走 } & $\begin{array}{l}\text { (1)グランドマーカーのかわりにミニハードルを置き、走り拢ける } \\
\text { (助走 } 15 \mathrm{~m}+5 \sim 6 \text { 台 })\end{array}$ \\
\hline & (2)マーカーとミニハードルをランダムに置き、広いストライドを保って走り抜ける \\
\hline \multirow[t]{3}{*}{ スタート練習 } & (1)いろいろな姿勢からの変形ダッシュ $(20 \mathrm{~m})$ \\
\hline & (2)片手をついたスタート等のドリル $(20 \mathrm{~m})$ \\
\hline & (3)クラウチングスタートによるスタートダッシュ \\
\hline \multirow[t]{2}{*}{ スプリント練習 } & フォームに気をつけながら、リラックスして走る（フロート） \\
\hline & 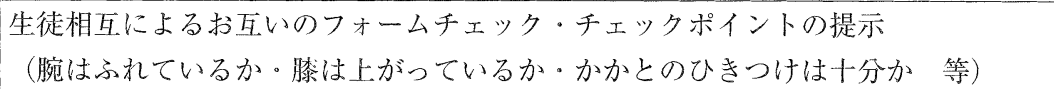 \\
\hline
\end{tabular}

<投運動 $>$

\begin{tabular}{|c|c|}
\hline 項目 & 内 \\
\hline バウンド投げ & 体重移動を意樴して、全身を使ってボールを地面に吒きつける \\
\hline 振り子投げ & $\begin{array}{l}\text { 両手を胸の前で合わせた状態から、両腕を円を描くように大きく外転させ、两手が肩の } \\
\text { 高さよりも高い位置にきたら一気に投げに移行する }\end{array}$ \\
\hline ステップ投げ & サイドステップからの投げ \\
\hline バトン投げ & バトンの端を握り、バトンをまっすぐ縦にできるだけ多く回転させるように投げる \\
\hline 叮く動作 & 少年用サッカーゴールのポスト上部を手に持ったヒモで吅く \\
\hline キャッチボール & $\begin{array}{l}\text { 注意すべきポイントを意識しながら行う } \\
\text { 2人組でのフォームチェック・チェックポイントの提示 } \\
\text { (肘の高さ・バックスイング・フォロースルー・リリースポイント・体重移動・ステップのタイミング等) } \\
\text { 遠投 }\end{array}$ \\
\hline ターボジャブ投げ & いろいろなものを投げてみる \\
\hline
\end{tabular}


宮㟝：高校生の体育授業にお梳る走・投能力向上の可能性

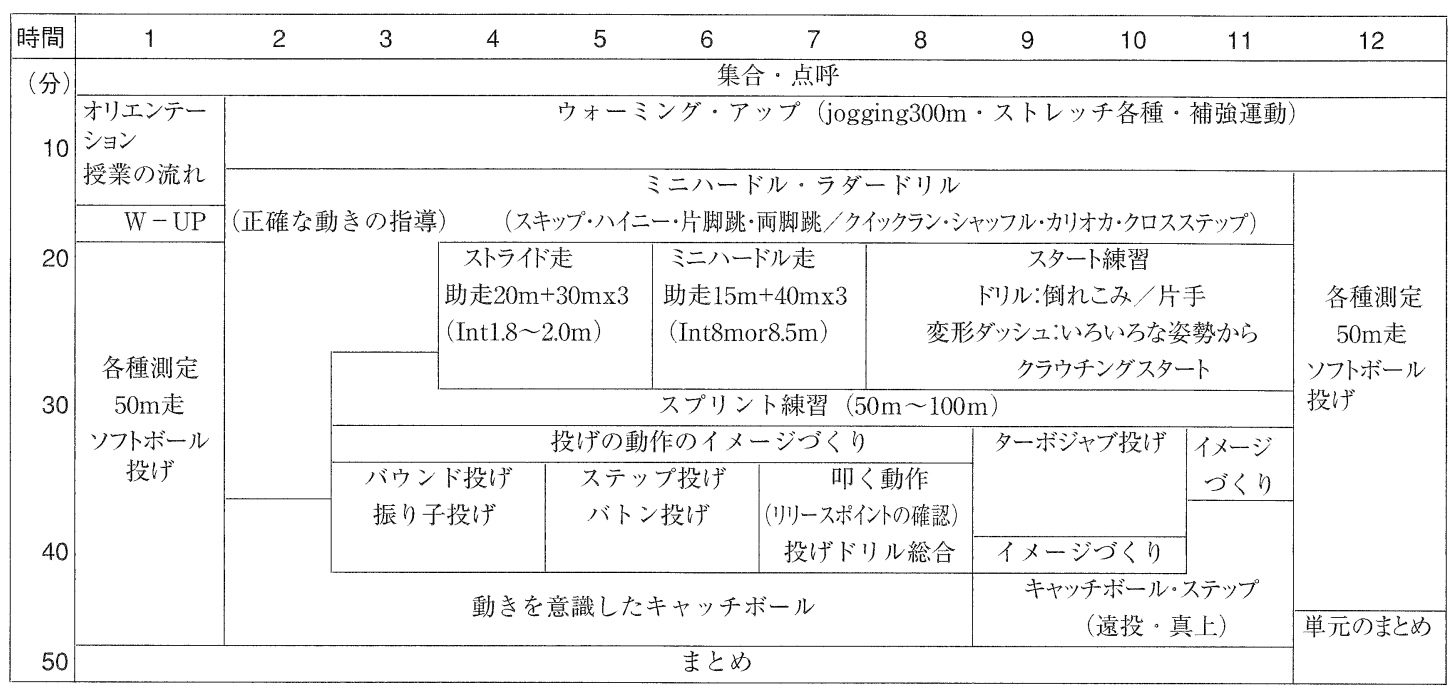

\section{図 1 単元の学習の流れ}

作の撮影を行った。100mにおいては1サイクル (2 歩) 以上の疾走動作が、ソフトボール投げに おいては準備動作からフォロースルーまでの全体 が画面に収まるように画角を調整した。

\section{（4）動作評価}

測定後に先行研究による動作評価基準（高本ら, 2003）を使用して、観察的動作評価を行った（表 3、4)。この評価法では走動作、投動作のそれぞ れに関して、もっとも未熟な動作をパターン 1 、 もっとも成熟した動作をパターン 5 として、全 5 パターンからなる動作パターンに分類されてい る。この評価基準は最も成熟したパターン 5 を特 別な運動経験のある成人の高度に成熟した動作に 設定しており、高校生にも十分適用できる基準で ある。評価の判定では動作の評価セクションごと に評価を行い、最も多く該当するパターンをその 対象者の動作パターンとした。また、動作の変化 を総合的に検討するために各セクションの得点の 合計も算出した。

\section{（5）データ処理}

上記（3）（4）のようにして得られた結果を用 い、学習前後の記録予よび動作得点の変化、男女 の差について $\mathrm{t}$ 検定（対応あり）を行い、学習に
よる変化を検討した。学習前後の記録と動作得点、 記録の伸びそれぞれについて Pearsonの積率相関 分析を行い、本研究に扮ける学習が生徒にどのよ うな影響を与えたのかを検討した。

\section{3. 結果と考察}

\section{（1）学習による変化}

表 5 に記録と動作得点の学習による変化を示し た。表に示すとおり男女ともに記録の向上、およ び動作に有意な変化が認められた。男子の $100 \mathrm{~m}$ 走、ボール投げでは記録、動作得点ともに $0.1 \%$ 水準で有意な変化が認められた。女子の $100 \mathrm{~m}$ 走 では記録と動作得点、ボール投げでは動作得点が $0.1 \%$ 水準、記録が $1 \%$ 水準で有意な変化が認め られた。動作評価はパターン1からパターン 5 ま での5段階であるが、詳しい変化の様子をみるた めに各セクションの得点合計を示した（以下「動 作得点合計」とする)。

学習による記録、動作得点合計の変化を示した 人数及び割合を表 6 に示した。男子の $100 \mathrm{~m}$ 走に おいて学習の前後で記録が向上した生徒は $93.2 \%$ で、記録が低下したのは6.8\%にあたる8名のみ であった。一方、ボール投げでは $67.5 \%$ の生徒が 記録を向上させ、31.6\%が記録の低下を示した。 $100 \mathrm{~m}$ の動作得点合計では $74.4 \%$ 、ボール投げで 


\section{表 3 走運動の観察的動作評価基準}

\begin{tabular}{|c|c|c|c|c|c|}
\hline & パターン1 & パターン 2 ， & パターン3 & パターン4 & パターン 5 \\
\hline \multirow[t]{2}{*}{ 腕振り } & ほとんど振らない & $\begin{array}{l}\text { 肘をわずかに屈曲さ } \\
\text { せ、左右に振る }\end{array}$ & $\begin{array}{l}\text { 前後に振るが、振り幅 } \\
\text { が小さい }\end{array}$ & 前後に振る & 前後に大きく振る \\
\hline & & $\begin{array}{l}\text { 肘を完全に屈曲させ、 } \\
\text { 体から離さず振る腕を }\end{array}$ & & & \\
\hline $\begin{array}{c}\text { 離地時 } \\
\text { 膝・足首の伸展 }\end{array}$ & $\begin{array}{l}\text { 屈曲したままで伸 } \\
\text { 展しない }\end{array}$ & 伸展が不十分 & $\begin{array}{l}\text { 伸展する傾向にあるが、 } \\
\text { まだ不十分 }\end{array}$ & 瞬間的に伸展する & 完全に伸展する \\
\hline $\begin{array}{l}\text { 回復期前半 } \\
\text { 足の蹴り上げ }\end{array}$ & $\begin{array}{l}\text { 蹴り上げが見られ } \\
\text { ない }\end{array}$ & 蹴り上げが小さい & $\begin{array}{l}\text { 蹴りあげるが、まだ不 } \\
\text { 十分 }\end{array}$ & 十分に蹴り上げる & $\begin{array}{l}\text { 警部方向へ十分に } \\
\text { 蹴り上げる }\end{array}$ \\
\hline $\begin{array}{c}\text { 回復期後半 } \\
\text { 大腿の引き上げ }\end{array}$ & $\begin{array}{l}\text { 引き上げが見られ } \\
\text { ない }\end{array}$ & $\begin{array}{l}\text { 地面鉛直面に対して } \\
45^{\circ} \text { より低い位置ま } \\
\text { で引き上げる }\end{array}$ & $\begin{array}{l}\text { 地面水平よりやや低い } \\
\text { 位置まで引き上げる }\end{array}$ & $\begin{array}{l}\text { 地面とほぼ水平か、 } \\
\text { い位置まで引き上げ } \\
\text { るやや低 }\end{array}$ & $\begin{array}{l}\text { 地面とほぼ水平ま } \\
\text { で引き上げる }\end{array}$ \\
\hline
\end{tabular}

高本ら（2003）による

表 4 投運動の観察的動作評価基準

\begin{tabular}{|c|c|c|c|c|c|}
\hline & パターン 1 & パターン 2 & パターン 3 & パターン 4 & パターン 5 \\
\hline 投げ手腕 & $\begin{array}{l}\text { 身体前面で保持した } \\
\text { 肘を屈曲させた姿勢 } \\
\text { から、そのまま肘を } \\
\text { 前下方に伸展させる }\end{array}$ & $\begin{array}{l}\text { 时を屈曲させたまま } \\
\text { 上方へ引き上げ、肘 } \\
\text { を前下方へ伸展させ } \\
\text { る }\end{array}$ & $\begin{array}{l}\text { 肘を屈曲させたまま } \\
\text { 上腕を外転·水平内 } \\
\text { 転させて、後方へ引 } \\
\text { き上げる }\end{array}$ & $\begin{array}{l}\text { 手首を反時計回りに } \\
\text { 循環させながら後方 } \\
\text { へ引き上げるが、ひ } \\
\text { じの伸展が不十分 }\end{array}$ & $\begin{array}{l}\text { 肩を中心として腕を } \\
\text { 反時計回りに循環さ } \\
\text { せながら、肘を伸展 } \\
\text { させ、肩のライン } \\
\text { り後方に引き、バッ } \\
\text { クスイングの最終局 } \\
\text { 面で掌を下に向ける }\end{array}$ \\
\hline $\begin{array}{c}\text { バックスイング時 } \\
\text { 体幹後傾 }\end{array}$ & 後傾していない & ほとんど後傾しない & わずかに後傾する & 後傾している & 大きく後傾している \\
\hline フォロースルー & $\begin{array}{l}\text { フォロースル—が見 } \\
\text { られない }\end{array}$ & $\begin{array}{l}\text { ほとんどフォロース } \\
\text { ル—が見られない }\end{array}$ & $\begin{array}{l}\text { わずかにフォロース } \\
\text { ル一が見られる }\end{array}$ & $\begin{array}{l}\text { 前下方への十分なフ } \\
\text { オロースル—が見ら } \\
\text { れる }\end{array}$ & $\begin{array}{l}\text { 肩を水平内転させな } \\
\text { がらの投げ手 }\end{array}$ \\
\hline 体重移動 & 体重移動しない & $\begin{array}{l}\text { ほとんど体重移動し } \\
\text { ない }\end{array}$ & $\begin{array}{l}\text { 体重移動はしている } \\
\text { が、投射時、フォロ } \\
\text { ースル一時ともにま } \\
\text { だ不十分 }\end{array}$ & $\begin{array}{l}\text { 投射時の体重移動は } \\
\text { 十分であるが、フォ } \\
\text { ロースルー時はまた } \\
\text { 不十分 }\end{array}$ & $\begin{array}{l}\text { 全体を通して後方か } \\
\text { ら前方へ、完全に体 } \\
\text { 重移動している }\end{array}$ \\
\hline \multirow[t]{2}{*}{ 足の踏み出し } & $\begin{array}{l}\text { 両足をそろえたま } \\
\text { ま、投げ手側足か投 } \\
\text { げ手反対側足を } 1 \text { 歩 } \\
\text { 出したまま }\end{array}$ & $\begin{array}{l}\text { 投げ手側足か投げ手 } \\
\text { 反対側足を前に小さ } \\
\text { く一歩踏み出す }\end{array}$ & $\begin{array}{l}\text { 投げ手側足か投げ手 } \\
\text { 反対側足から前方へ } \\
\text { ステップする }\end{array}$ & $\begin{array}{l}\text { 投げ手側足か投げ手 } \\
\text { 反対側足から前方へ } \\
\text { ステップする }\end{array}$ & $\begin{array}{l}\text { 投げ手側足か投げ手 } \\
\text { 反対側足から前方へ } \\
\text { ステップし、大きく } \\
1 \text { 歩踏み出す }\end{array}$ \\
\hline & $\begin{array}{l}\text { 投げ手側の足を前に } \\
\text { 小さく一歩踏み出す }\end{array}$ & & & & \\
\hline \multirow[t]{2}{*}{ 体幹回転 } & $\begin{array}{l}\text { 投射方向へ正対した } \\
\text { ままで体幹は回転し } \\
\text { ない }\end{array}$ & $\begin{array}{l}\text { 投射方向へ体幹は正 } \\
\text { 対したままで、方が } \\
\text { わずかに回転する }\end{array}$ & $\begin{array}{l}\text { バックスイング時に } \\
\text { 後方へ回転する }\end{array}$ & $\begin{array}{l}\text { バックスイング時に } \\
\text { 後方へ回転する }\end{array}$ & $\begin{array}{l}\text { バックスイング時に } \\
\text { 投射方向のラインよ } \\
\text { ク後方へ大きく回転 } \\
\text { する }\end{array}$ \\
\hline & & & & $\begin{array}{l}\text { 投射時の前方へのね } \\
\text { じり戻しの回転が見 } \\
ら れ る\end{array}$ & $\begin{array}{l}\text { 投射時に肩を水平内 } \\
\text { 転させなな゙ら、回転 } \\
\text { させる }\end{array}$ \\
\hline 投げ手反対腕 & 下げたまま & 前下方へ小さく出す & $\begin{array}{l}\text { 前方へ突き出すが、 } \\
\text { 投射時の体幹方向へ } \\
\text { の引き戻しは見られ } \\
\text { ない }\end{array}$ & $\begin{array}{l}\text { 前方へ突き出し、投 } \\
\text { 射時に投射時に体幹 } \\
\text { 方向へ引き戻す }\end{array}$ & $\begin{array}{l}\text { 前上方に突き出し、 } \\
\text { 投射時に体幹方向へ } \\
\text { 引き戻す }\end{array}$ \\
\hline
\end{tabular}


は $72.7 \%$ \%゙伸びを示し、動作も著しく改善したと いえる。一方、女子の $100 \mathrm{~m}$ 走の記録では $61.1 \%$ が記録を伸ばし、動作得点合計については $94.7 \%$ が改善されている。ボール投げでも記録は $64.2 \%$ が向上し、動作得点合計においては $100 \%$ 改善を 示し、変化のない者は一人もいなかった。

学習による記録の向上、動作の改善にどの学習 プログラムが有効であったかについて考察を加え ると、走運動では回復期前半の足の蹴り上げや回 復期後半の大腿の引き上げの改善をねらった、ミ ニハードルを使ったドリル各種と、学習前の被験 者のストライドが狭いことを授業者が観察的に評 価し、それを改善しようとしたストライド走が有 効であったと考えられる。投運動では走運動より も動作得点の向上が顕著であったが、学習前では 特に女子において基礎的な動作が身についていな い者が多く、体幹が横を向き、投げ手が後方に引 かれ、投げ手反対腕が前方に突き出されるという 準備動作ができていないために、体幹の回転を使 って投げることができていない者が多かった。こ の特徵は尾縣・関岡（1995）によって成人女性の
投動作の特徴のひとつとして報告されており、先 述のとおり本研究で使用した学習プログラムのね らいとするところでもある。学習プログラムの中 でも、体幹を横に向けて構え、投げ手と投げ手反 対腕を開いて投げに移行する「振り子投げ」のド リルが有効であったと考えられる。

記録が向上しなかった者に関しても動作得点は 向上した者が多く、これに関しては後に考察を加 える。

ボール投げに扔いて、個人内での 5 回の試技の 最高値と最低值の差を学習の前後で比較すると、 学習前よりも学習後のほうが差は小さくなる傾向

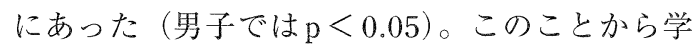
習によって安定性が増し、失敗投てきが減少した と考えられる。

\section{（2）学習による変化の性差}

表 7 は学習による記録と動作得点合計の変化量 を男女別に示し、比較したものである。

$100 \mathrm{~m}$ 走の記録の変化は、女子よりも男子の方 が有意に大きかった $(\mathrm{p}<0.001)$ 。しかしながら、

表 5 学習前後の記録および動作評価・得点合計の平均值および標準偏差

\begin{tabular}{|c|c|c|c|c|c|c|c|c|}
\hline & & & \multicolumn{3}{|c|}{ 男子（N=117） } & \multicolumn{3}{|c|}{ 女子（N=95） } \\
\hline & & & 前 & 後 & & 前 & 後 & \\
\hline \multirow{6}{*}{$100 \mathrm{~m}$} & 記録 & 平均 & 14.74 & 14.15 & $* * *$ & 17.38 & 17.16 & **** \\
\hline & (秒) & 標準偏差 & 0.85 & 0.71 & & 0.93 & 0.89 & \\
\hline & 動作評価 & 平均 & 4.3 & 4.7 & $* * * *$ & 3.7 & 4.4 & $* *$ \\
\hline & （5段階） & 標準偏差 & 0.60 & 0.46 & & 0.66 & 0.58 & \\
\hline & 動作得点合計 & 平均 & 17.1 & 18.5 & : & 14.9 & 17.6 & $\Rightarrow$ \\
\hline & （20点満点） & 標準偏差 & 1.69 & 1.24 & & 2.17 & 1.71 & \\
\hline \multirow{8}{*}{ ボール投げ } & 5回平均 & 平均 & 41.13 & 43.19 & was & 19.24 & 20.36 & 烽 \\
\hline & (m) & 標準偏差 & 9.84 & 10.08 & & 5.25 & 5.30 & \\
\hline & 最高值 & 平均 & 44.22 & 45.78 & $=$ & 21.22 & 22.08 & $\Rightarrow$ \\
\hline & (m) & 標準偏差 & 10.07 & 10.13 & & 5.60 & 5.49 & \\
\hline & 動作評価 & 平均 & 4.2 & 4.6 & 皮 & 3.2 & 4.1 & 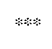 \\
\hline & （5段階） & 標準偏差 & 0.70 & 0.50 & & 0.55 & 0.54 & \\
\hline & 動作得点合計 & 平均 & 29.4 & 31.8 & 䋓 & 22.3 & 28.3 & *as \\
\hline & （35点満点） & 標準偏差 & 4.00 & 2.39 & & 3.45 & 2.94 & \\
\hline
\end{tabular}


表 6 学習による記録および動作得点合計の向上・低下を示した人数と割合

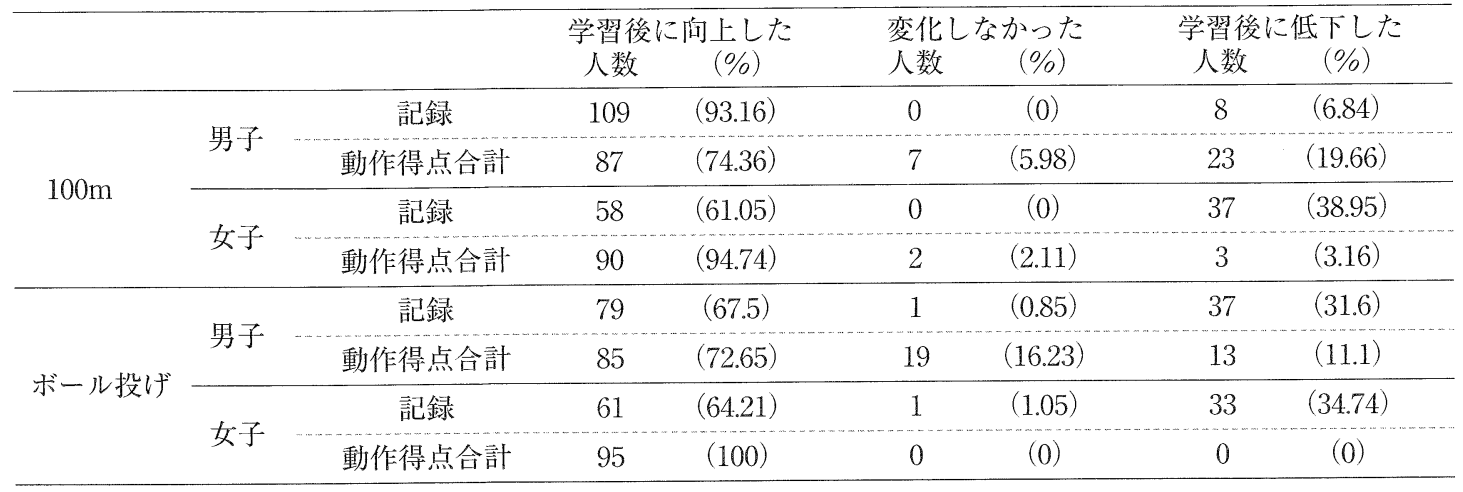

男子 $\mathrm{n}=117$ ，女子 $\mathrm{n}=95$

動作得点合計の変化は $100 \mathrm{~m}$ 走、ボール投げのい ずれにおいても男子よりも女子の方が有意に大き く（p<0.001）、その結果、表5が示すように、 学習後の女子の動作得点合計は、100m走では学 習前の男子の動作得点合計を上回り、ボール投げ では学習前の男子の動作得点合計に近づいた。

投能力のトレーニング効果については、男子の 方が効果は大きいとする研究（宮下ら 1977, 水 野ら 1976）と、女子の方が効果は大きいとする 研究（宮丸ら 1982，奥野ら 1989）が存在するが、 本研究においては特に動作に関して女子の方が学 習による変化が大きかった。高校生を対象とした 先行研究が少ないため比較は難しいが、この結果 は小学校 1 年生から中学校 3 年生を対象とした研 究結果（奥野ら 1989）と同様であった。また走 能力については、思春期後期である高校生の時期 にピークを迎える男子と比較して、女子はその身 体的な成熟が運動遂行の上でマイナスの要因とな り、疾走速度の増大は見られずむしろ停滞から減 少の傾向を示すことが明らかにされている（加藤 ら 1994）。経年的には疾走能力が顕著に向上しな いとされる高校生女子において、本研究では特に その走動作について学習による変化が認められ、 動作得点の向上は男子よりも顕著に見られた。

本研究において走動作、投動作のいずれにおい ても女子の方が顕著に改善された理由として、女 子の学習前の動作得点が全般的に低く、改善の余 地が大きいことがあげられる。実際の指導場面で は、基本的な動きに関する指導者のアドバイスで、
即座に動作が改善されることも多く、本授業にい たるまでの基碟的運動動作の指導の不足が伺われ た。

\section{（3）記録と動作評価のかかわり}

記録と動作のかかわりは、女子では $100 \mathrm{~m}$ 走、 ボール投げはともに高い相関関係にあった（p< $0.001)$ が、男子においては $100 \mathrm{~m}$ 走 $(\mathrm{p}<0.01)$ がボール投げ $(\mathrm{p}<0.001)$ よりも相関関係が弱か

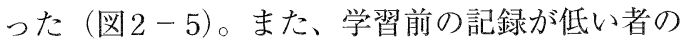
ほうが、学習による記録の伸びは高い傾向にあっ たが、男女抢よび運動によってその傾向には違い が見られた（図6-9）。100m走では動作の変化 は学習前の記録にかかわりがないが、記録の伸び は学習前記録の低い者のほうが大きい傾向にあ る。一方、ボール投げでは、動作の変化は学習前 記録の低い者のほうが大きいが、記録の伸びは学 習前記録にかかわりがないといえる。この傾向は 男子でより顕著に見られた。また、学習によって 記録と動作得点合計が変化した被験者の割合（表 6）をみても、女子の $100 \mathrm{~m}$ 走においては全体の 94.7\%が動作を改善させているにもかかわらず、 38.9\%が記録を低下させている。ボール投げに関 しては100\%が動作を改善させているにもかかわ らず、34.8\%が記録を低下させている。これらの ことは動作の改善が即座に記録の向上につながら ない場合もあることを示しており、他の要因が働 いていると考えられる。

深代ら（1982）は幼児の投能力に関する報告の 
宮㠃：高校生の体育授業における走・投能力向上の可能性

表 7 学習による記録および動作得点合計の変化量と標準偏差（男女比較）

\begin{tabular}{|c|c|c|c|c|c|}
\hline & & & 男子（n=117） & 女子 $(\mathrm{n}=95)$ & \\
\hline \multirow{2}{*}{$100 \mathrm{~m}$} & $\begin{array}{l}\text { 記録 } \\
\text { (秒) }\end{array}$ & $\begin{array}{c}\text { 平均 } \\
\text { 標準偏差 }\end{array}$ & $\begin{array}{r}-0.59 \\
0.46 \\
\end{array}$ & $\begin{array}{r}-0.22 \\
0.59\end{array}$ & $s$ \\
\hline & 動作得点合計 & $\begin{array}{c}\text { 平均 } \\
\text { 標準偏差 }\end{array}$ & $\begin{array}{l}1.3 \\
1.37\end{array}$ & $\begin{array}{l}2.7 \\
1.66\end{array}$ & - \\
\hline \multirow{2}{*}{ ボール投げ } & $\begin{array}{l}\text { 記録 } \\
(\mathrm{m})\end{array}$ & $\begin{array}{c}\text { 平均 } \\
\text { 標準偏差 }\end{array}$ & $\begin{array}{l}1.55 \\
3.42\end{array}$ & $\begin{array}{l}0.86 \\
2.96\end{array}$ & \\
\hline & 動作得点合計 & $\begin{array}{c}\text { 平均 } \\
\text { 標準偏差 }\end{array}$ & $\begin{array}{l}2.4 \\
2.62\end{array}$ & $\begin{array}{l}6.1 \\
2.61\end{array}$ & $=$ \\
\hline
\end{tabular}

中で、フォーム得点が低くて投距離が高いものは ほとんどいないが、フォーム得点が高くても投距 離が低いものが存在し、動作の改善が距離の増大 に結びつかない場合があることを指摘している。 本研究におけるその理由は明らかにできなかった が、まだ慣れない動作を忠実に再現しようとする あまり動きがぎこちなくなったり、力が入ってし まったりしてスピードがなくなってしまったこ と、走運動における身体全体の姿勢や投運動にお ける手の部分やスナップなど、本研究で使用した 評価項目に含まれない部分の動きや身体各部の動 きのバランス、運動のリズムなどもその原因とし て考えられる。また、短期間の体育授業では動作 の定着までにはいたらず、さらに学習時間が必要 であることも推察された。

\section{（4）学習による変化の顕著な者について}

学習による記録の変化が顕著な者について動作 得点との関係を表 8 に示した。男子の $100 \mathrm{~m}$ 走で 最も記録を伸ばした者は $14.8 \%$ の伸びであった が、動作得点合計は1ポイント改善したのみであ った。記録が最も低下した者の低下率は $-1.9 \%$ で、動作得点合計も1ポイント低下していた。女 子では最も記録を伸ばした者は $12.4 \%$ の伸びで、 動作得点合計は 1 ポイントの改善、記録が最も低 下した者はー8.2\%低下していたにもかかわらず、 動作得点合計は 2 ポイント向上していた。このよ うに $100 \mathrm{~m}$ 走については男女とも記録の変動は比 較的小さく、動作の変化では、前傾姿勢が不足で あごが上がり気昧になるなど姿勢の問題が見受け
られたが、それほど顕著な変化は見られなかった。 これに対してボール投げでは、記録の向上が顕著 な者は動作得点合計の向上も顕著で、女子で変化 の最も大きかった者は 11 ポイントの向上であっ た。記録の低下が顕著であった者も動作得点は向 上が見られ、動作が改善しても記録が向上しない という先に述べた特徴が示唆された。男子で最も 記録が低下した者は、動作得点合計は 4 ポイント 向上しているが記録は $17.4 \%$ 低下している。動き の特徵を示すと、学習前は肩が回らず时の伸展だ けで投げていたが、学習後にはバックスイングが 大きくなり、肩が回るようになった。しかしなが ら学習後では、慣れない動きを忠実に再現しよう とする様子が見受けられ、ぎこちない動きになっ たために振り切りのスピードが逑くなり、記録の 低下につながったものと考えられる。また、女子 で最も記録を低下させた者は、動作得点合計は 6 ポイント向上しているものの記録は $28.2 \%$ 低下し ている。学習前は構えの時点で肘の位置が低く、 押し出すように投げていたが、学習によりバック スイングができるようになり、投げ手反対腕も準 備できるようになった。しかしこの投げ手反対腕 をタイミングよく使うことができず、フォロース ルーができていない。またボールの握り方とスナ ップに問題があるが、この項目については今回の 動作評価基準で評価することはできなかった。

\section{（5）現場への示唆}

本研究では高等学校の体育授業を通して走・投 の運動動作を中心に指導することによって、男女 


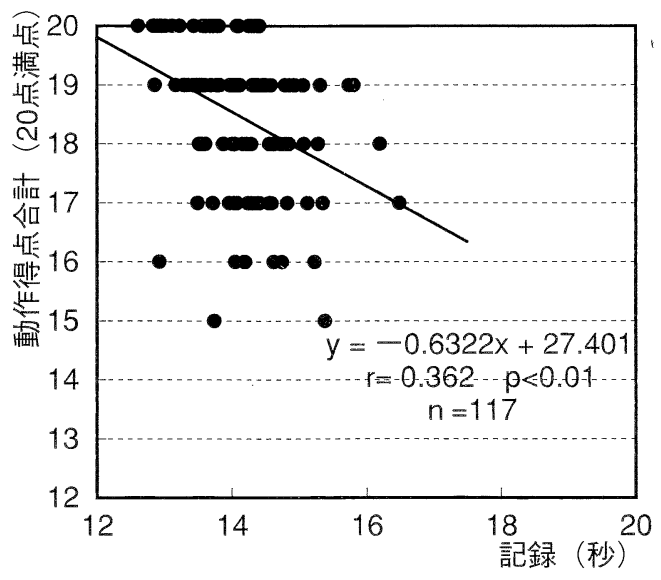

図 2 男子 $100 \mathrm{~m}$ : 学習後の記録と動作得点の関わり

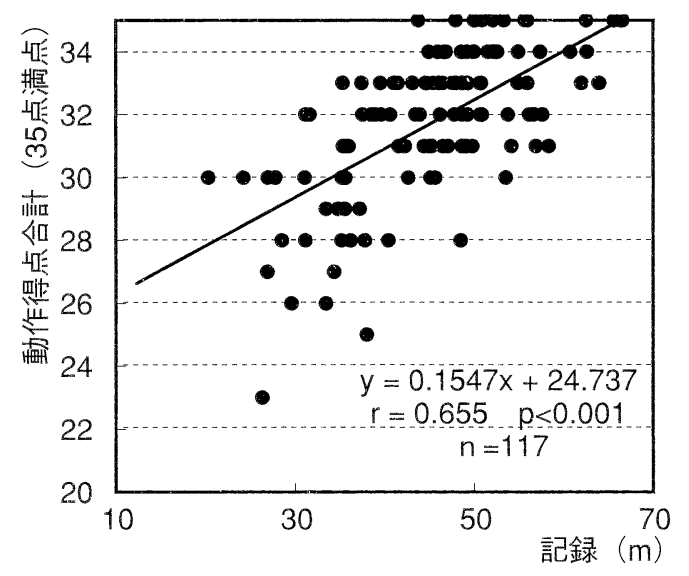

図 4 男子ボール投げ：学習後の記録と動作得点の関 わり

ともに運動動作を改善させ、記録を向上させるこ とができた。このことは体育授業において運動動 作を指導することの重要性を示唆している。本研 究で実施した授業においては、学習を進める中で 生徒が自らの課題に向かって試行錯誤し、それを お互いに観察し指摘しあい、学習の成果に気づく ことができるように工夫して授業を展開した。実 際の授業における技能の指導では、ただ単調にそ

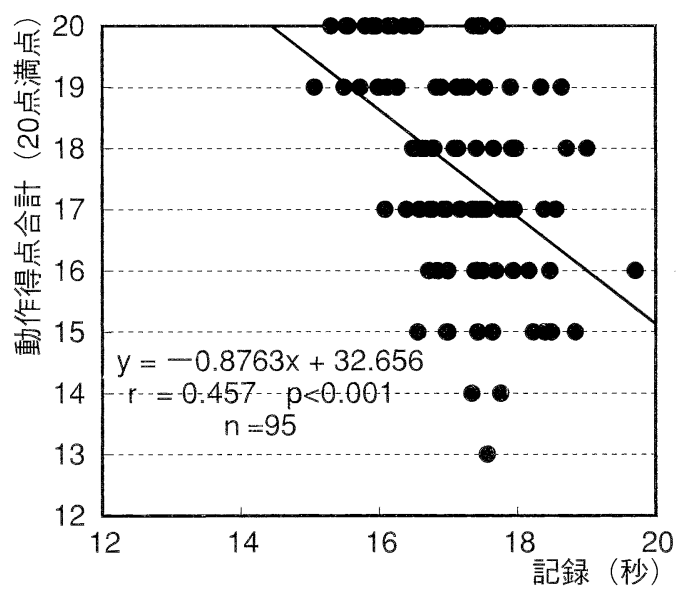

図 3 女子 $100 \mathrm{~m}$ : 学習後の記録と動作得点の関わり

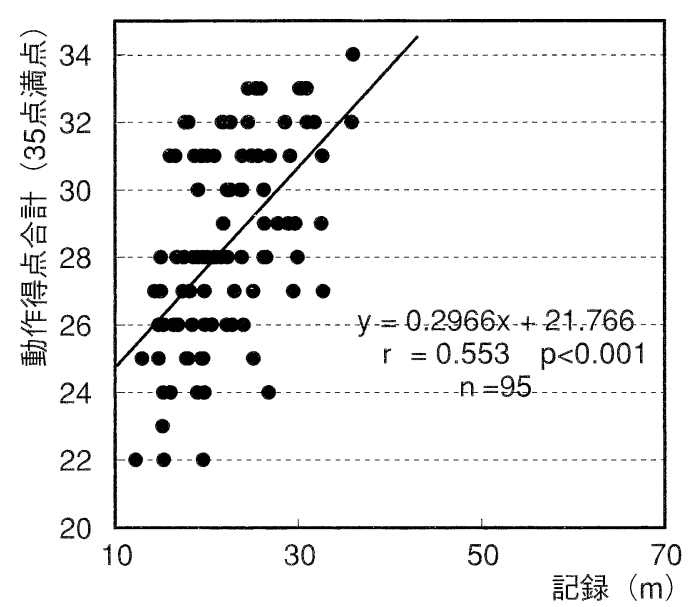

図 5 女子ボール投げ：学習後の記録と動作得点の関 わり

の運動を繰り返すのではなく、生徒に目標とする 運動のポイントを明確に示し、生徒個人にあった 個別指導を行うことにより生徒が自分にあった目 標や課題を見つけることができるようにすること が必要であると思われる。授業の結果、生徒の大 半が動作を改善することができたが、記録の向上 につながらない者もいた。本研究においてその原 因は明らかにできなかったが、動作の変化が即座 


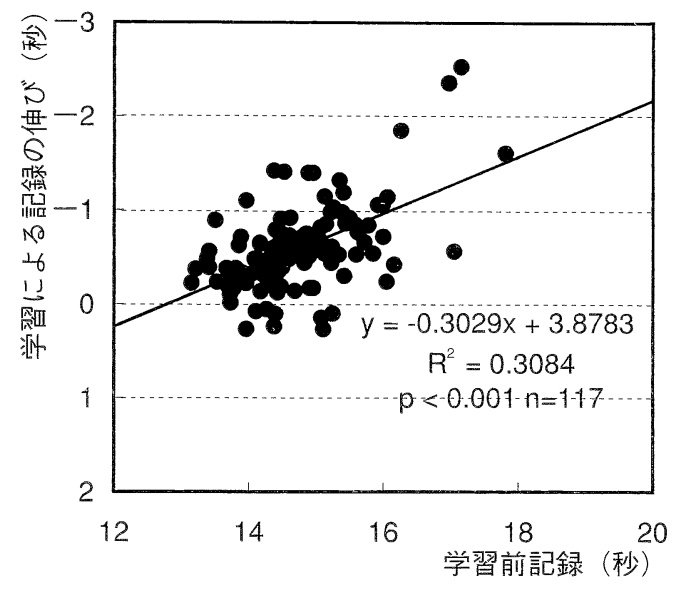

図6 男子 $100 m$ : 学習前記録と伸びとの関わり

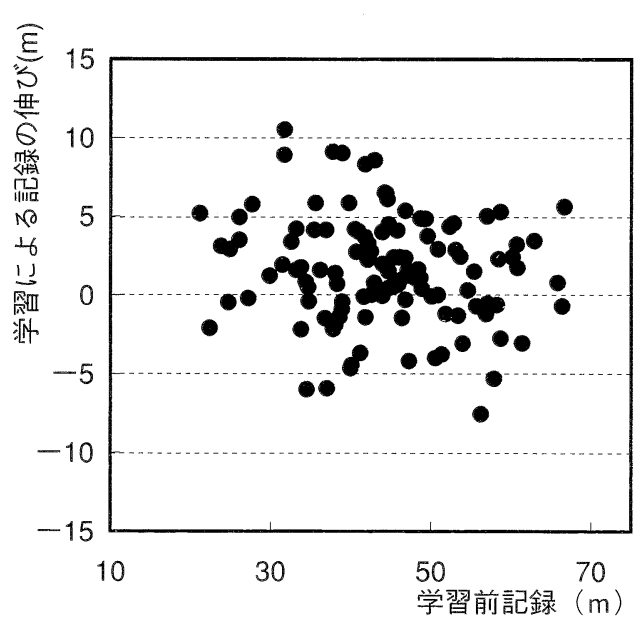

図 8 男子ボール投げ：学習前記録と伸びとの関わり

に記録の向上につながらなかった生徒も、授業内 には記録は向上しなかったものの、今後も正しい 動作の定着を目指し運動を続けることで向上する 可能性がある。また生涯スポーツにつながる意味 でも基礎的運動動作の習得は重要な意義があり、 学習者に理解させる必要があると考える。運動動 作の指導にはそれぞれ適時性があると考えられ、 走・跳・投のような基礎的運動動作は、できるだ け早期から指導されることが望ましい。しかし現

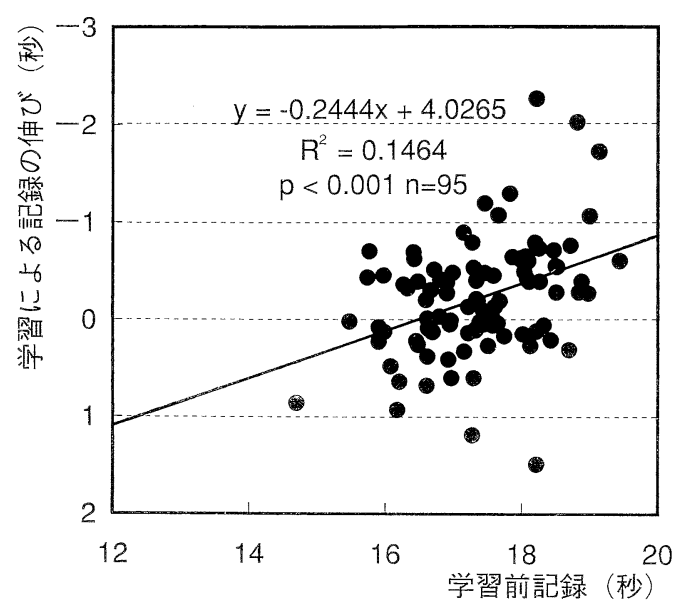

図 7 女子 $100 m$ ：学習前記録と伸びとの関わり

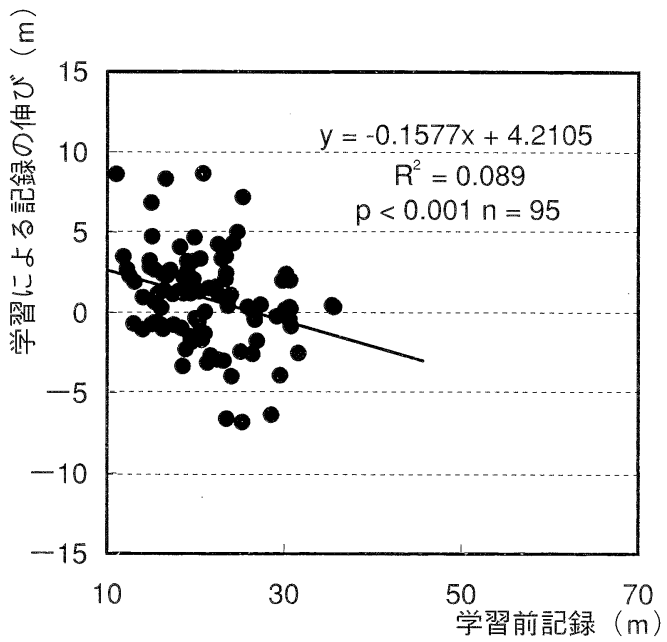

図 9 女子ボール投げ：学習前記録と伸びとの関わり

状ではこれらの基礎的運動動作は「できてあたり まえ」とされ、運動動作自体を指導されることは 稀である。学習指導要領に示されると扔り、「基 礎・基本」を大切にするならばこのような基礎的 運動動作の指導こそ見直されるべきである。それ によってその上に積み重㸚られていく、さまざま な運動能力も土台から改善されるであろう。

運動能力の二極化が問題となっている今、運動 動作が未熟で運動の苦手な者はその苦手意識から 
表 8 学習前後で記録変化の顕著な者の動作得点の変化

\begin{tabular}{|c|c|c|c|c|c|c|}
\hline & \multicolumn{3}{|c|}{ 記録 } & \multirow{2}{*}{$\begin{array}{c}\text { 動作得点合計 } \\
\text { の変化 } \\
\end{array}$} & \multicolumn{2}{|c|}{ 学習後に変化した項目 } \\
\hline & & の変化 & び率 (\%) & & 得点向上 & 得点低下 \\
\hline \multirow{4}{*}{$\begin{array}{c}100 \mathrm{~m} \\
\text { 記録向上 } \\
\text { (秒) }\end{array}$} & 男 & -2.53 & 14.75 & 1 & 腕振り & \\
\hline & 男 & -2.35 & 13.90 & 1 & 腕振り、大腿の引き上げ & 回復期前半の蹴り上げ \\
\hline & 女 & -2.26 & 12.40 & 1 & 大腿の引き上げ & \\
\hline & 女 & -2.02 & 10.73 & 2 & 腕振り、離地時の滕、足首の伸展 & \\
\hline \multirow{4}{*}{$\begin{array}{c}100 \mathrm{~m} \\
\text { 記録低下 } \\
\text { (秒) }\end{array}$} & 男 & 0.27 & -1.93 & -1 & & 大腿の引き上げ \\
\hline & 男 & 0.27 & -1.79 & -3 & & $\begin{array}{l}\text { 離地時の膝・足首の伸展・回復期前 } \\
\text { 半の蹴り上げ }\end{array}$ \\
\hline & 女 & 1.49 & -8.18 & 2 & 離地時の膝・足首の伸展、大腿の引 & \\
\hline & 女 & 1.19 & -6.89 & 0 & & 大きなフォームの変化は見られない \\
\hline \multirow{4}{*}{$\begin{array}{c}\text { ボール投げ } \\
\text { 記録向上 } \\
(\mathrm{m})\end{array}$} & 男 & 10.51 & 33.10 & 8 & $\begin{array}{l}\text { 体幹の後傾、体重移動、足の踏み出 } \\
\text { し、体幹の回転、反対腕 }\end{array}$ & \\
\hline & 男 & 8.90 & 28.08 & 8 & すべての項目 & \\
\hline & 女 & 8.61 & 78.13 & 3 & 体幹の後傾・反対腕の使用 & \\
\hline & 女 & 8.31 & 50.06 & 11 & すべての項目 & \\
\hline \multirow{4}{*}{$\begin{array}{c}\text { ボール投げ } \\
\text { 記録低下 } \\
(\mathrm{m})\end{array}$} & 男 & -6.0 & -17.39 & 4 & 足の踏み出し以外すべて & 体重移動 \\
\hline & 男 & -5.92 & -15.98 & 6 & 反対腕の使用以外すべて & \\
\hline & 女 & -6.62 & -28.17 & 6 & 反対腕の使用以外すべて & \\
\hline & 女 & -6.82 & -27.00 & 3 & 体重移動、足の踏み出し、体幹回転 & \\
\hline
\end{tabular}

積極的に運動をせず、運動の得意な者は積極的に 運動をすることでその差はさらに開いていくとい う悪循環が起こっている。本研究において、学習 前の記録が低い者のほうが、学習による記録の伸 びが高い傾向にあったことは、運動の苦手な者の 底上げを意味しており、雨者の差を縮めることに つながるであろう。運動の苦手な者が運動動作を 改善することによって授業以外でもその運動に積 極的に取り組むようになれば、その业循環を断ち 切ることができ、少しでも運動の二極化に歯止め をかけられるのではないだろうか。

本研究の結果、体育授業を通して高校生の男女 に走・投能力向上の可能性が認められたことは、 成長の一段落した高校期の体育授業においても、 運動能力の向上や動作の改善を目標にして体育授 業を進めることの意義を認め、体育授業のひとつ のあり方を示すものである。

\section{4.まとめ}

本研究の結果は以下のとおり要約できる。

1） $100 \mathrm{~m}$ 走、ソフトボール投げのそれぞれについ て男女ともに記録の向上、動作の改善がみら れた。

2）女子では $100 \mathrm{~m}$ 走、ボール投げともに記録と動
作との相関関係が強かったが、男子において は $100 \mathrm{~m}$ 走がボール投げよりも相関関係が弱か った。

3）学習前に記録の低かった者のほうが、学習に よる記録の伸びは高い傾向にあったが、男女 および運動によってその傾向には違いが見ら れた。特にボール投げについては、動作の改 善が直接記録の向上につながらない例が見受 けられた。

4） $100 \mathrm{~m}$ 走、ボール投げともに、記録と動作の両 面に扔いて性差は大きかった。学習による伸 びも同様であったが、動作に関しては男子よ りも女子の方が、伸びが大きい傾向があった。 その結果、女子は学習後に男子の学習前の動 作得点に近い水準に達した。

以上のことから、高校生の男女には体育の授業 を通して動作を改善させ、走・投能力を向上させ る可能性があることが認められた。

\section{参考文献}

出村慎一（1993）幼坚期におけるボール遠投に対 する体力および投運動の貢献度とその性差. 体育学研究 37 : 339-350.

深代千之・稲葉勝弘 - 小林規 ·宮下充正（1982） 
幼児に見られる投能力の発達. J.J.SPORTS

SCI.1 : 231-236.

加藤謙一・山中任広・宮丸凱史・阿江通良 (1992)

男子高校生の疾走能力および最大無酸素パワ

一の発達. 体育学研究 37 ：291-304.

加藤謙一・宮丸凱史・阿江通良（1994）女子高校

生の疾走能力および最大酸素パワーの発達。

体育学研究 $39 ： 13-27$.

金善應・松浦義行（1988）幼児期における基礎運

動技能の量的変化と質的変化に関する研究。

体育学研究33-1：27-38

宮丸凱史・平木場浩二（1982）幼児のボールハン

ドリング技能に㧍ける協応性の発達（3）-

投動作様式の発達とトレーニング効果一。体

育科学 $10 ： 111-124$.

宮丸凱史・加藤謙一（1990）成長にともなう疾走

能力の発達。体育の科学 $40: 775-780$

宮下充正・桜井伸二・斉田ゆかり・井上和雄

（1977）幼児に見られるボール投げの練習効

果：昭和 52 年度日本体育協会スポーツ科学

研究報告, No.IV : 投能力の向上に関する研

究, 1-2, 32-33.

水野忠和・角田俊幸・辻博明・宮下充正（1976）

成人女子および 18 歳女子の投能力 : 昭和 51

年度日本体育協会スポーツ研究報告, No.1,
投能力の向上に関する研究，24-28.

日本 SAQ協会（1999）スポーツスピード養成

「SAQトレーニング」。大修館書店。

尾縣貢・市村操一（1995）パス解析を用いたオー バーハンドスロー動作の検討：成人女性を対

象として。体育学研究 40：170-180

尾縣貢・関岡康雄・飯田稳（1996）成人女性にお

ける投能力向上の可能性。体育学研究 41 :

11-22。

尾縣貢・高橋健夫。高本惠美・細越淳二。関岡康 雄（2001）オーバーハンドスロー能力改善の ための学習プログラムの作成：小学校 $2 \cdot 3$ 年生を対象として。体育学研究 $46 ： 281$ 294 .

奥野暢通・後藤幸弘・过野昭 (1989) 投運動学習 の適時性に関する研究一小・中学生のオーバ ーハンドスローの練習効果からー。スポーツ 教育学研究 $9: 23-35$.

桜井伸二（1991） スポーツ科学ライブラリー 5 。

投げる科学. 大修館書店。

高本恵美 - 出井雄二 · 尾縣貢 (2003) 小学校児童 における走，跳および投動作の発達：全学年 を対象として。スポーツ教育学研究 $23 ： 11$ 15.

平成 20 年 8 月 1 日 受付

平成 21 年 3 月 23 日 受理 